\title{
Cyberslacking Facts of Organization: Determinants and Impact
}

\author{
${ }^{1}$ Richika Shekher, ${ }^{2}$ Prof. Rijuta Joshi \\ ${ }^{1}$ Student, Shri Ramdeobaba College of Engineering and Management, Nagpur \\ ${ }^{2}$ Assistant Professor, Shri Ramdeobaba College of Engineering and Management, Nagpur \\ Email: shekherrs@rknec.edu,joshir1@rknec.edu
}

\section{Received: $20^{\text {th }}$ September 2018, Accepted: $11^{\text {th }}$ October 2018, Published: $31^{\text {st }}$ October 2018}

\begin{abstract}
Cyberloafing is a term used to describe the actions of employees who use their internet access at work for personal use. Cyberloafing has two primary forms minor cyberloafing (eg. Sending and receiving personal emails at work) and serious cyber loafing (eg. Online gambling, surfing adult oriented web site). Due to growth in technology it has increased the chances of an individual to cyberloaf in workplace. Internet has made the boundaries between work and non-work (home) less distinct by mixing the personal work in workplace and doing organizational work at home. The purpose is to study the influence of cyberslacking on task performance of employees and considering the impacts of cyberslacking on the organizations. This study is in term of the organisation. This study examines the cyberloafing phenomenon, explains the determinants of cyberloafing in organization and analyzes its positive and negative impacts as well as controlling methods.
\end{abstract}

\section{Keywords}

Cyberloafing, Cyberslacking, Controlling Measures, Determinants and Impact.

\section{Introduction}

Big changes took place throughout the world, in last couples of decade. There occurred the great technological advancement change. Internet had dramatic effect on people's lives. Most significant changes which covers the way of information's age by development of Information and Technology and the internet. In the recent years, abuse of company's internet resources by employees has received a considerable amount of attention among organization. The means of production have been improved because of computer and other electronic devices by automating certain activities and by supporting employees in their daily task. Internet technologies had brought enormous benefits to part of both personal and business lives and it is unavoidable. Organization had identified and connected the potential offered by internet, and as a tool for enhancing employee performance. Internet had played an important role in helping reducing cost of businesses, to reduce product cycle time and give efficient services. According to survey of employees, $90 \%$ admitted engaging in non-work related web surfing at work and $84 \%$ said they sent personal e-mail at work $^{[1]}$.

As par the definition of cyberloafing is act of employees using their organizations internet access for personal purpose during working hours. Examples of cyberloafing include sending and receiving e-mails to friends and family, posting updates on social networking sites such as Facebook and Twitter, going shopping online, visiting entertainment websites and downloading software such videos, music and games. As cyberloafing is rapidly increasing it is important for the organizations to understand why employees engage themselves in cyberloafing at workplace, so that organizations can effectively manage employee's internet usage at work. In $2002,56 \%$ of employees used internet for personal use ${ }^{[2]}$. In $2003,59 \%$ of employees used internet for non-work related things ${ }^{[3]}$. And in 2005, cyberslacking had become the most common ways for employees to waste time during working hours $^{[4]}$.

Main focus is to understand the potential use of personal computers at work its causes and consequences. Due to cyberloafing it can lead to reduction in productivity, an inefficient use of network resources and resulting in an uncompetitive organization ${ }^{[5],[6],[7],[8]}$. Tendency of using the internet for entertainment and other non-work purpose on the job by employees is more common ${ }^{[9]}$.The study aims on the non-work related computing of cyberloafing, part history and consequences as well as controlling measures.

\section{Methods and Materials}

The data collected for this paper is the secondary data. The secondary data is gathered from the existing papers which had been published. Then overview the policies of the different companies of cyberloafing for the employees. The reason for collecting the data from these sources was as the researchers had already done certain kind of study on the related topic it was helpful and data was reliable to be used. Referring different company's policies helped to find out how the practical the organizations are dealing with cyberloafing. 


\section{Results and Discussion}

\section{(A) Impact of Cyberslacking on Task Performance}

The main focus is to study the impact on task performance due to cyberloafing; mainly there is a negative effect on productivity.

The First perspective is that cyberslacking domino effect is on lower task performance as there is loss of work time ${ }^{[10],[11]}$. If, instead, the time is spent on working it would result into high productivity than loss in productivity ${ }^{[10],[11]}$.

The Second perspective is that certain kind of behavior due to cyberloafing is more harmful. The social behaviors can harm the productivity. As relationship building activities requires more energy, time, intellectual resources ${ }^{[12]}$. It impacts more strongly on task performance because of behavior such as web-browsing.

The Third perspective can be overlooked as positive impact of cyberloafing on employees. Cyberloafing can help employees to get rid of work stress and it also gives a pause or a relaxation time to the employees from continuous work which could result into increasing in productivity ${ }^{[13],[14]}$. Boost in productivity could be considered as overcoming any losses in productivity happened due to cyberslacking ${ }^{[15]}$. Therefore there is a positive relationship between cyberloafing and task performance of the employees.

The Fourth perspective is that cyberslacking does not put impact on task performance when done little but does impacts the task performance when done at extreme extent ${ }^{[9]}$. So, by this we can say that every employee have a different working standard; each one of them are not equally productive. So after every employee matches the level of standard work, they can go for cyberloafing in leftover time. According to this perspective cyberloafing should have a small relationship between cyberslacking and task performance.

\section{(B) Consequences of Cyberloafing}

Cyberloafing is misuse of internet at workplace. Therefore there are two consequences of cyberslacking. One side is it could be helpful for both employees and the organization and at another side it could be harmful also as it prevents employees from being productive. Many researchers came up with the concept that cyberloafing is wasteful activity and creates problem for the organization. Other researcher came up with the concept that cyberslacking is not harmful for the organisation as employees work for long time they can cyberloaf and fresh up their mind so that it could lead to creativity, flexibility and for better learning environment ${ }^{[9]}$.

\section{(i) Positive Consequences}

Always cyberloafing is depicted as negative behavior of employees as it leads to the losses in productivity or time loss but there is a positive aspect it gives relief from boredom, tiredness, stress, gives more job satisfaction, develops creativity and overall employees would be dedicated towards their job ${ }^{[16]}$. It had been observed that employees using internet more frequently are highly satisfied than those who use internet less ${ }^{[17]}$. Some days employees tries to escape from their routine work that time cyberloafing plays vital role to form positive behavior towards work ${ }^{[18]}$. We can consider cyberloafing as an 'office toy' for employees to motivate them to work and it can reduce work stress also $^{[19]}$. Thus we can say cyberslacking plays a positive impact on employees.

\section{(ii) Negative Consequences}

There are increasing actions reported against cyberloafing in the organization ${ }^{[20]}$. Organizations have experienced negative consequences in terms of disciplinary behavior, loss of employees, confidentially issues or privacy problems ${ }^{[8]}$. Due to cyberslacking organizations are facing problems of reduction in productivity, unproductive use of network resources and uncompetitive organisation ${ }^{[21]}$. Cyberslacking is destructive and establishes a form of employee deviance ${ }^{[22]}$. Therefore we can say that cyberloafing increases the use of network resources, which causes security problems and it may happen that there could be exposure to viruses and also hackers.

\section{(C) Controlling Measures of Cyberloafing}

Organizations are facing common problem now a days of cyberloafing ${ }^{[23]}$. As it is increasing problem therefore there is a need to understand the controlling measure. Adverse effects faced by the organization cannot be neglected and also we should consider the positive impacts on employees. Some methods by which organizations can control the cyberloafing behavior of the employees, the methods are listed as follows: (i) educating and informing employees, (ii) adapting computer use policies, (iii) establishing monitoring systems, (iv) enforcement through punishment.

\section{(i) Educating and Informing}

Implementing any method unless it is a properly managed and awareness of improvement is not explained suitably ${ }^{[5]}$. Training should be given towards the negative consequences towards cyberloafing. Self-control can be 
simply gained by awareness of employees and telling them about the relationship between performance and cyberslacking and its negative impact on their productivity ${ }^{[16]}$.

\section{(ii) Computer Use Policies}

Now a day's computer is an essential part of workplace almost each and every employee is having an individual computer to work. To control cyberloafing in this condition managers/ management should implement clear policies in regard to usage of internet at workplace ${ }^{[18]}$. Employees should be clearly told about the internet usage policy, about the potential consequences regarding the abuse of internet at workplace ${ }^{[24]}$.

\section{(iii) Monitoring}

Cyberloafing behaviors of employees at workplace can be controlled by electronic monitoring systems ${ }^{[5]}$. It can be controlled by either deny the access of sites and monitoring emails can reduce cyberloafing, the employees who does cyberloafing in high amount can also be controlled by this ${ }^{[25]}$.

\section{(iv) Punishment}

Monitoring activities of employees can efficiently impact the usage internet at workplace. Punishing individuals for doing cyberloafing can be an example for other employees for abuse of internet ${ }^{[25]}$. Only punishment is not a good way to deal but also controlling systems is essential ${ }^{[26]}$.

\section{Conclusion}

Cyberloafing has relationship with task performance. There are two kinds of relationship one is negative and another is positive. But as we studied above more over there are negative relationships between cyberslacking and task performance. When we come to the consequences of cyberloafing there are two types' positive consequences and negative consequences. While studying any topic we should study both aspect of the topic. So as there are negative consequences of cyberloafing like privacy problems, misuse of network resources and uncompetitive organization but there are positive aspect also which cannot be neglected as it reduces the boredom form work, stress, it helps to be creative and flexible. For the problems of increasing abuse of internet we can implement the controlling measures.

\section{References}

[1] Naughton, K., Raymond, J., \& Shulman, K. (1999). Cyberslacking. Newsweek, 134, 62-65.

[2] Greengard, S. (2002). The high cost of cyberslacking. Workforce, 12(December), 22-24.

[3] Griffiths, M. (2003). Internet abuse in the workplace: Issues and concerns for employers and employment counselors. Journal of Employment Counseling, 40, 87-96.

[4] Malachowski, D. (2005). Wasted time at work costing companies billions. Retrieved December 15, 2005, from http://www.salary.com/careers/layoutscripts/crel_display.asp?tab=cre\&cat=nocat\&ser=Ser374\&part=Par555.

[5] Chen, J. V., Chen, C. C., \& Yang, H. (2008). An empirical evaluation of key factors contributing to internet abuse in the workplace. Industrial Management \& Data Systems, 108, 87-106.

[6] Scheuermann, L. S., \& Langford, H. P. (1997). Perceptions of Internet abuse, liability, and fair use. Perceptual and Motor Skills, 85, 847-850.

[7] Stewart, F. (2000). Internet acceptable use policies: Navigating the management, legal, and technical issues. Security Management, 9, 46-52.

[8] Weatherbee, T. G. (2010). Counterproductive use of technology at work: Information \& communications technologies and cyberdeviancy. Human Resource Management Review, 20, 35-44.

[9] Blanchard, Anita L. and Christine A. Henle (2008), "Correlates of Different Forms of Cyberloafing: the Role of Norms and External Locus of control", Computers in HumanBehavior, Vol.24, pp.1067-1084.

[10] Barlow, J., Bean, L. A., \& Hott, D. D. (2003). Employee "spy" software: Should you use it? Journal of Corporate Accounting \& Finance, 14(4), 7-12.

[11] Foster, M. (2001). Be alert to the signs of employee Internet addiction. National Public Accountant 46, 39-40.

[12] Lim, V. K. G., \& Chen, D. J. Q. (2009). Cyberloafing at the workplace: Gain or drain on work? Behaviour \& Information Technology, 25(1), 1-11.

[13] Belanger, F., \& Van Slyke, C. (2002). Abuse or learning? Communications of the ACM, 45(1), 64-65.

[14] Block, W. (2001). Cyberslacking, business ethics and managerial economics. Journal of Business Ethics, 33(3), 225-231.

[15] Mirchandani, D., \& Motwani, J. (2003). Reducing Internet abuse in the workplace. Advanced Management Journal, 68(1), 22-26.

[16] Vitak, Jessica, Julia Crouse and Robert LaRose, (2011), "Personal Internet use at work: Understanding Cyberslacking", Computers in Human Behavior, Vol.27, pp.1751-1759. 
[17] Stanton, J. M. (2002), "Company Profile of the Frequent Internet User", Communications of the ACM, Vol.45, No.1, pp.55-59.

[18] Beugre, Constant D. and Daeryong, Kim (2006), “Cyberloafing: Vice or Virtue?" in Mehdi Khosrow-PourEd.book, Emerging Trends and Challenges in Information Technology Management, pp.834-835.

[19] Anandarajan, Murugan and Claire A., Simmers (2005), "Developing Human Capital Through Personal Web Use in the Workplace: Mapping Employee Perceptions", Communications of the Association for Information Systems, Vol.15, pp.776-791.

[20] Garrett, R. Kelly and James N. , Danziger (2008), "Disaffection or Expected Outcomes: Understanding Personal Internet use During Work", Journal of Computer-Mediated Communication, Vol.13, pp. 937-958.

[21] Liberman, Benjamín and Gwendolyn Seidman, Katelyn Y.A. McKenna, Laura E. Buffardi (2011), "Employee Job Attitudes and Organizational Characteristics as Predictors of Cyberloafing", Computers in Human Behavior, Vol.27, pp. 2192-2199.

[22] Lim, Vivien K. G. (2002) "The IT way of Loafing on the Job: Cyberloafing, Neutralizing and organizational justice”, Journal of Organizational Behavior, Vol.23, pp.675-694.

[23] Lim, Vivien K.G. and Thompson S.H., Teo (2005), "Prevalence, Perceived Seriousness, Justification and Regulation of Cyberloafing in Singapore an Exploratory Study", Information and Management, Vol.42, pp.1081-1093.

[24] Woon, Irene M.Y. and Loo Geok, Pee (2004), "Behavioral Factors Affecting Internet Abuse in the Workplace", Proceedings of the Third Annual Workshop on HCI Research in MIS, Washington, D.C., December 10-11, 2004.

[25] Ugrin, Joseph C., J. Michael Pearson and Marcus D., Odom (2008), "Cyber-Slacking: Self-Control, Prior Behavior and The Impact Of Deterrence Measures" Review of Business Information Systems, Vol.12, No.1, pp.75-87.

[26] Zoghbi-Manrique-de-Lara, Pablo and Arístides, Olivares-Mesa, (2010) "Bringing Cyber loafers Back on the Right Track", Industrial Management and Data Systems, Vol.110, No.7, pp.1038-1053 